\title{
Suitability of Selected Seed Genotypes of Prunus armeniaca L. for Harvesting Seeds for the Production of Generative Rootstocks for Apricot Cultivars
}

\author{
Marek Szymajda ${ }^{1}$, Kris Pruski ${ }^{2}$, Edward Żurawicz ${ }^{1} \&$ Mirosław Sitarek ${ }^{1}$ \\ ${ }^{1}$ Research Institute of Horticulture, Konstytucji 3 Maja 1/3, 96-100 Skierniewice, Poland \\ ${ }^{2}$ Department of Plant \& Animal Sciences, Dalhousie University, Truro, Canada \\ Correspondence: Marek Szymajda, Research Institute of Horticulture, Konstytucji 3 Maja 1/3, 96-100 \\ Skierniewice, Poland. Tel: 48-46-834-5406. E-mail: Marek.Szymajda@inhort.pl
}

Received: June 29, 2013 Accepted: July 25, 2013 Online Published: August 15, 2013

doi:10.5539/jas.v5n9p222 URL: http://dx.doi.org/10.5539/jas.v5n9p222

\begin{abstract}
In 2008-2011, at the Research Institute of Horticulture in Skierniewice, Poland seven genotypes of Prunus armeniaca $\mathrm{L}$., designated $\mathrm{MN}-1, \mathrm{MN}-2$, MN-4, MN-6, MN-46, MN-53 and MN-59, were evaluated for use as trees to provide seeds for the production of generative rootstocks for apricot cultivars. The study was conducted on trees growing in the Experimental Orchard in Dąbrowice (central Poland). The best as seed trees proved to be genotypes MN-4 and MN-46. Their flower buds are resistant to frost, the flowers are well able to tolerate spring frosts, and the trees yield regularly and produce a lot of small fruit. Trees of these genotypes are also characterized by a relatively low growth vigour and produce seeds with a high germination capacity. The results indicate that genotypes MN-4 and MN-46 are very suitable for harvesting seeds for the production of generative rootstocks for apricot cultivars in countries located in the seasonally cold regions of the temperate climate which represent the northernmost extent of apricot cultivation.
\end{abstract}

Keywords: stratification, germination capacity, rootstocks for apricot

\section{Introduction}

The apricot (Prunus armeniaca L.) is an important species of fruit plants cultivated on a large production scale in the temperate climate zone. In recent years, global production of apricots has been at a fairly stable level of about 3.5 million tonnes of fruit (FAO, 2011). Various varieties of apricot are cultivated around the world; the rootstocks used for these cultivars are primarily generative rootstocks, most often seedlings of $P$. armeniaca, and, to a lesser extent, P. cerasifera Ehrh. (Southwick \& Weis, 1998; Indreias, Stefan, \& Dutu, 2004; Orero et al., 2004). In many countries where apricots are grown on a large scale, such as Italy, France, Iran, Syria, Turkey and China, one can come across commercial apricot orchards with trees grafted on rootstocks produced from seeds of local wild apricot trees (Rom, 1991; Vachun, 1995; Chokoeva \& Marinov, 1999; Geuna, Toschi, \& Bassi, 2003). In some countries, seedlings of cultivated varieties, such as 'Veecot' and 'Haggith' in Canada or 'Manicot' in France, are also used as rootstocks for apricot (Jakubowski, 2004). Because of the variety of generative rootstocks used in the cultivation of apricot and various drawbacks associated with them, many breeding centres around the world are conducting research on obtaining special seed genotypes of apricot whose seeds can be harvested and used to produce generative rootstocks suitable for the cultivated varieties of apricot. Such types have already been selected in the Czech Republic, Hungary and Germany (Jakubowski, 2004).

In Poland, the rootstock commonly used in the cultivation of apricot is the Myrobalan plum (P. cerasifera). Myrobalan seedlings as rootstocks for cultivated varieties of apricot are also used in Bulgaria, the Czech Republic, France and Hungary (Audergon, Duquesne, Nicolas, \& Caudubert, 1991; Suranyj, 1999; Dimitrowa \& Marinov, 2002). However, the Myrobalan plum, apart from many advantages, such as being well adapted to Polish soil and climate conditions, produces symptoms of incompatibility with many cultivated varieties of apricot (Grzyb, Zdyb, \& Sitarek, 1996). As a result, trees of the cultivars grafted on it yield poorly, and often die prematurely or break in a strong wind (Jakubowski, 2004). In addition, the Myrobalan plum as a generative rootstock produces numerous root suckers, which make weed control in the orchard difficult and are feeding sites for aphids, the known vectors of the Plum Pox Virus that causes the sharka disease. By contrast, apricot 
seedlings do not have these disadvantages. Used as rootstocks for apricot cultivars, they are highly compatible with most of the cultivated varieties of apricot (Vachun, 1995) and do not produce root suckers (Southwick \& Weiss, 1998). For that reason, the Research Institute of Horticulture in Skierniewice, Poland, has been engaged over the last years in conducting research on the selection of genotypes within the P. armeniaca species that could serve as seed trees to supply seeds for the production of generative rootstocks for apricot cultivars.

Apricot seed trees should bear fruit regularly and abundantly, that is, produce annually a large number of fruit, which are the source of stones (seeds) for the production of generative rootstocks. However, in a climate where there are harsh winters, i.e. in countries such as Poland, Canada, Russia, Latvia, Belarus, flower buds of apricot trees are often damaged by low subzero temperatures (Szymajda, Pruski, Żurawicz, \& Sitarek 2013). As a consequence, after some winters, apricot trees yield poorly, or even do not produce any fruit (seeds) at all. Therefore, in order to ensure annual fruiting of seed trees and continuity in the supply of seeds for the production of generative rootstocks, apricot seed orchards in countries located in colder regions of the temperate climate should be established with genotypes sufficiently well adapted for cultivation in those regions. For that reason, one of the main directions of apricot breeding in Poland, which, like Canada, is the northernmost country for apricot cultivation, is the selection of seed genotypes that can reliably supply seeds for the production of generative rootstocks in a seasonally cold climate. In countries with such a climate, apricot trees should be able to tolerate injuries to flower buds caused not only by low subzero temperatures during endodormancy but also by temperature fluctuations during ecodormancy, as well as be tolerant to spring frosts that can damage buds and flowers before and during flowering.

The harvested seeds should have a high germination capacity. However, apricot seeds, like the seeds of other species of trees of the genus Prunus, after extraction from the fruit are incapable of germination because they are in a state of deep physiological rest (Suszka, 1962). The seeds attain the capacity for germination only after some time, during post-harvest maturation that occurs during a treatment called stratification. During the treatment, seeds are kept in an environment with the right temperature, humidity and oxygen supply (Suszka, 1962, 1967; Duczmal \& Tucholska, 2000; Jakubowski, 2004). The optimum temperature for apricot seed stratification is in the range between +2 and $+4^{\circ} \mathrm{C}$. At a temperature of about $0^{\circ} \mathrm{C}$ and above $+6^{\circ} \mathrm{C}$, the dose of chilling needed to overcome the resting phase is accumulated by seeds more slowly and germination is delayed (Jakubowski, 2004). According to Suszka (1967), the period of stratification until germination of the first apricot seeds is from 77 to 98 days, while Fadl, Bass, and Tayel (1978, as per Polat, 2007) obtained the best seed germination rate in the 72nd day of stratification. Jakubowski (2004) reported that apricot seeds require at least 50 days of stratification, the duration being dependent on the genotype of the seeds. Knowing the length of the stratification period required to break the internal resting of seeds is essential in nursery practice. On the basis of it and the planned date for sowing seeds in the nursery, the date to commence the stratification treatment is determined.

The aim of this study was to evaluate the suitability of trees of several genotypes of $P$. armeniaca for use as seed trees to supply seeds for the production of generative rootstocks for apricot cultivars and to assess the capacity of the harvested seeds for germination.

\section{Material and Methods}

\subsection{Experimental Site and Plant Material}

The study was conducted in 2008-2011 by the Research Institute of Horticulture in Skierniewice, on apricot trees growing in the Experimental Orchard in Dąbrowice (central Poland). The seed trees under evaluation represented seven genotypes of Prunus armeniaca denoted by the symbols: MN-1, MN-2, MN-4, MN-6, MN-46, MN-53 and MN-59. These genotypes were selected at the Institute of Pomology (now Research Institute of Horticulture) by Dr. Tadeusz Jakubowski. The exact origin and parental forms of the genotypes are not known. Measurements and observations were made on four trees of each genotype grafted on Myrobalan seedlings. Assessments of the intensity of flowering and fruiting of the trees were conducted in 2008-2010. Germination capacity of the seeds of genotypes MN-2, MN-4, MN-6 and MN-59 was tested in 2009-2011, and of MN-1, MN-46 and MN-53 in 2010-2011.

\subsection{Flowering and Fruiting of Trees}

Flowering time (full bloom) - determined as the date when about $50 \%$ of the flower buds on the tree had reached the fully open flower stage.

Fruit ripening time - this date was determined on the basis of the change in skin colour on the fruit from green to white or yellow in about $10 \%$ of the fruit, the accompanying softening of the flesh and the ease of separation of the stalk from the fruit-bearing shoot. 
Intensity of flowering and fruiting - assessed on a 1-9 point scale, where: 1 - no flowering or fruiting, 3 - poor flowering or fruiting, 5 - moderate flowering or fruiting, 7 - abundant flowering or fruiting, 9 - very abundant flowering or fruiting.

Mean fruit weight $(\mathrm{g})$ - determined as the average weight of one fruit based on 4 samples of ripe fruit, each consisting of 20 apricots. The samples were taken at fruit ripening time, randomly from four trees, at half their height, from the outer part of the crown.

Method of obtaining stones - the stones for testing were collected successively from ripe fruit fallen to the ground, showing no signs of decay. The remains of the flesh were removed by repeatedly washing the stones under running water. Stones floating on the surface of water (indicating a poorly developed seed) were eliminated. The stones were subsequently dried at room temperature and after drying were stored in paper bags in room conditions.

Weight of one dried stone $(\mathrm{g})$ - determined on the basis of 5 samples of 20 stones each. The samples were taken at random from a batch of stones within each genotype, prior to stratification.

Number of stones obtained from one tonne of fruit - calculated by dividing the weight of one tonne in grams $(1,000,000$ grams) by mean fruit weight in grams.

Number of dried stones per one kilogram - expressed as the ratio of the weight of one kilogram in grams $(1,000$ grams) and the weight of one dried stone in grams.

\subsection{Seed Germination}

Germination capacity - expressed as the percentage of seeds germinated during stratification in relation to the total number of stones stratified within each genotype. Each seed genotype (experimental combination) was represented by five replications, each being a bag containing 100 stones. Prior to stratification, in mid-January of each year of the study, the stones were disinfected with $0.5 \%$ solution of the fungicide Captan 50 WP (suspension, $50 \%$ captan) by soaking for 24 hours. Disinfected stones were mixed with a moist substrate in a 1: 3 ratio by volume (one part stones to three parts substrate). The substrate was a mixture of peat and sand in a 3:1 ratio by volume (three parts peat to one part sand). The stones mixed with the substrate were packed in plastic bags, in which holes had been made beforehand to ensure air supply, and subjected to stratification. Bags with stones to be stratified were placed in an incubator for seed germination at a temperature of about $+4^{\circ} \mathrm{C}$. The first inspection of the stones, in order to ventilate and check soil moisture, was carried out after 20 days, and the second after 40 days from the beginning of stratification. Subsequent inspections were conducted every 10 days; during the inspections stones with germinating seeds were taken out and counted. Seeds were considered germinated if the stone was cracked and a 5-10 $\mathrm{mm}$ long radicle was visible.

\subsection{Tree Growth Vigour}

An assessment of this characteristic of seed trees was undertaken only in the autumn of 2011 by measuring the circumference of the trunk at a height of $30 \mathrm{~cm}$ above the ground. On this basis the trunk cross-sectional area (TCSA) of the seed trees was calculated.

\subsection{Weather History}

During the winter months (December-March) (Figure 1a-c) and in the spring (April-May) (Figure 2a-c), minimum, maximum and average air temperatures were recorded at a height of about 1.8 metres above the ground. In the months of April to August (every year), average monthly temperatures and total monthly rainfall were recorded (Table 1).

Table 1. Characteristics of the weather during the growing seasons in the years of harvesting apricot seeds (Dąbrowice, 2008-2010)

\begin{tabular}{|c|c|c|c|c|c|c|c|c|}
\hline \multicolumn{5}{|c|}{ Average monthly temperature $\left({ }^{\circ} \mathrm{C}\right)$} & \multicolumn{4}{|c|}{ Total monthly rainfall (mm) } \\
\hline & Month & 2008 & 2009 & 2010 & Month & 2008 & 2009 & 2010 \\
\hline 1 & April & 8.3 & 10.0 & 8.8 & April & 23.2 & 11.0 & 16.0 \\
\hline 2 & May & 12.6 & 12.5 & 12.4 & May & 62.8 & 68.0 & 129.4 \\
\hline 3 & June & 17.5 & 22.7 & 16.6 & June & 11.8 & 146.0 & 62.6 \\
\hline 4 & July & 18.6 & 18.9 & 20.4 & July & 52.4 & 77.2 & 76.6 \\
\hline 5 & August & 18.2 & 17.7 & 18.7 & August & 92.2 & 29.0 & 123.2 \\
\hline \multicolumn{2}{|c|}{ Average } & 15.0 & 16.4 & 15.4 & Sum & 242.4 & 331.2 & 407.8 \\
\hline
\end{tabular}


A)

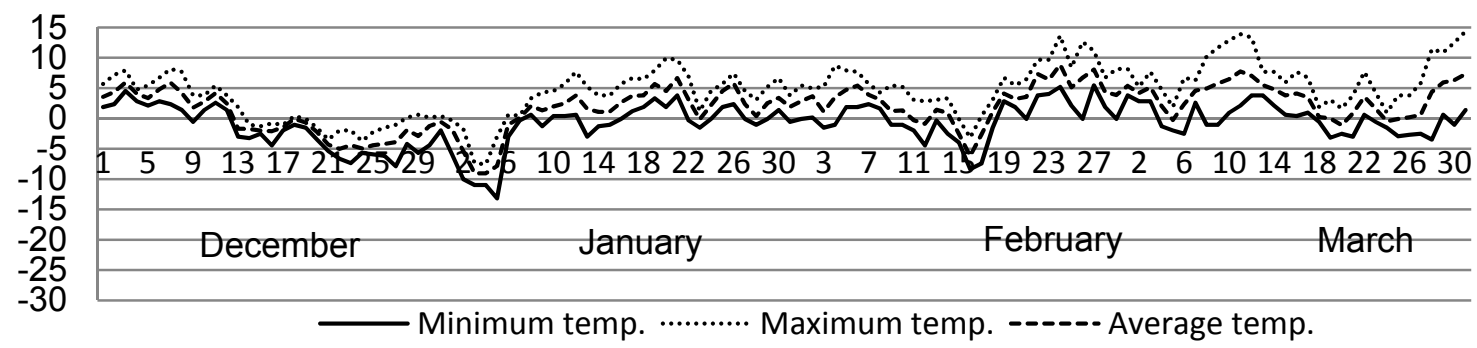

B)
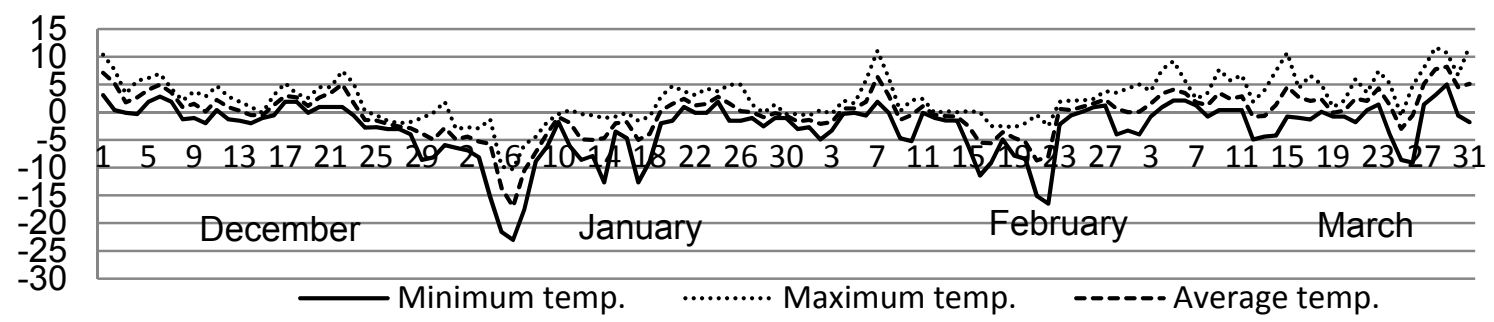

C)

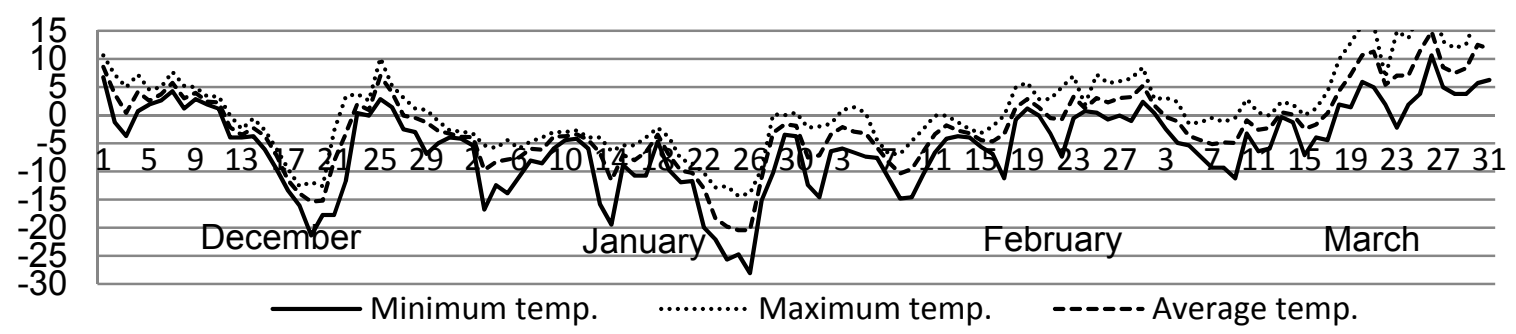

Figure 1. Temperature log: A) winter 2007/2008, B) winter 2008/2009, C) winter 2009/2010 
A)

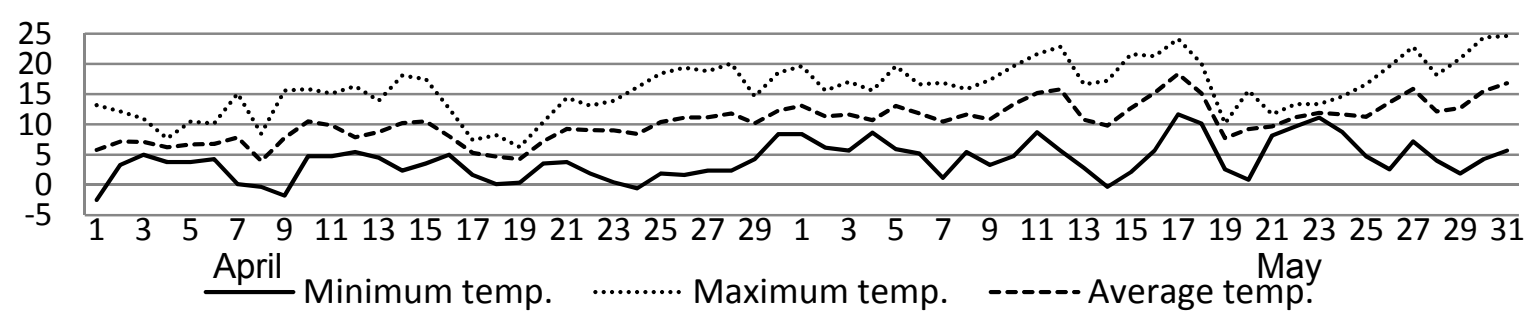

B)

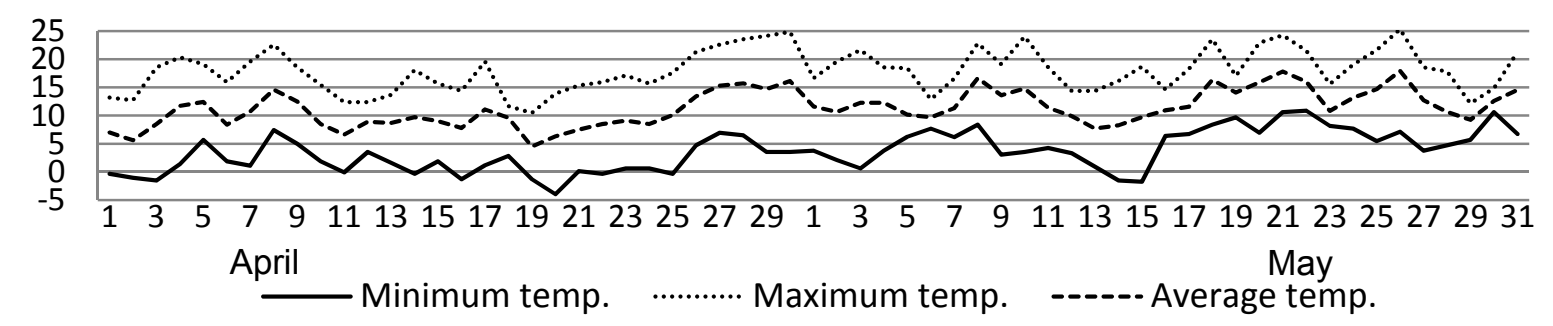

C)

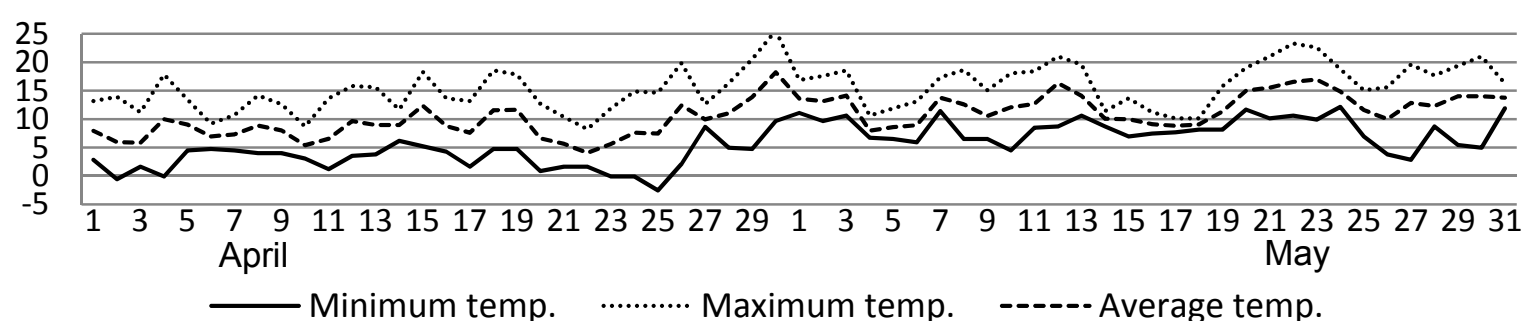

Figure 2. Temperature log during flowering and fruiting of apricot trees: A) spring 2008 (full bloom April 12-16), B) spring 2009 (full bloom April 16-20), C) spring 2010 (full bloom April 18-20)

\subsection{Statistical Analysis}

Experimental data were statistically analysed by R.A. Fischer's analysis of variance. Differences between means were assessed with Duncan's t-test at a 5\% level of significance.

\section{Results and Discussion}

\subsection{Flowering and Fruiting of Trees}

Despite the fact that a drop in temperature down to $-23.0^{\circ} \mathrm{C}$ was recorded during the $2008 / 2009$ winter (6 Jan 2009), and again down to $-28.1^{\circ} \mathrm{C}$ during the $2009 / 2010$ winter (26 Jan 2010) (Figure 1a-c), all the evaluated genotypes produced satisfactory crops of fruit both in 2009 and 2010. However, the most abundantly flowering and fruiting trees were those of genotypes MN-4 and MN-46 (Table 2 and 3). According to Szabo, Soltesz, Buban and Nyeki (1995), extensive winter injuries to flower buds of apricot trees in Hungary occur when the temperature drops to $-26^{\circ} \mathrm{C}$ in January, $-22^{\circ} \mathrm{C}$ in February, and $-16^{\circ} \mathrm{C}$ in March. In Poland, substantial damage to apricot flower buds, amounting in some genotypes to more than $90 \%$, already occurs when the temperature in February drops to $-20.1^{\circ} \mathrm{C}$ (Jakubowski, 2001). The authors' own studies have shown that severe freezing of apricot buds during January frosts occurs when the temperature falls to $-23.0^{\circ} \mathrm{C}$. However, this is not a common rule. During some winters, when trees are in a state of endodormancy, some flower buds are able to withstand a temperature drop even down to $-28.0^{\circ} \mathrm{C}$ (Szymajda et al., 2013). This indicates that the degree of damage to flower buds of apricot trees is dependent not only on the large drop in temperature but also on temperature fluctuations during winter and the different response of cultivars to winter frosts. The abundant flowering of trees of MN-4 and MN-46 genotypes observed in our study after large drops in temperature during the winters of 2008/2009 and 2009/2010 is evidence of a high resistance of their flower buds to winter frosts. 
Table 2. Flowering time (full bloom) and intensity of flowering of the evaluated apricot seed genotypes (Dąbrowice, 2008-2010)

\begin{tabular}{lllllllll}
\hline \multirow{2}{*}{ Genotype } & \multicolumn{9}{l}{ Flowering time (full bloom) } & \multicolumn{7}{l}{ Intensity of flowering* } \\
\cline { 2 - 9 } & \multicolumn{3}{l}{ Year of observation } \\
\cline { 2 - 9 } & 2008 & 2009 & 2010 & Average & 2008 & 2009 & 2010 & Average \\
\hline MN-1 & 12.04 & 17.04 & 18.04 & 16.04 & 7 & 5 & 4 & 5.3 \\
MN-2 & 14.04 & 17.04 & 19.04 & 17.04 & 7 & 6 & 4 & 5.7 \\
MN-4 & 13.04 & 16.04 & 18.04 & 16.04 & 8 & 7 & 9 & 8.0 \\
MN-6 & 13.04 & 18.04 & 18.04 & 16.04 & 8 & 7 & 7 & 7.3 \\
MN-46 & 13.04 & 16.04 & 18.04 & 16.04 & 9 & 6 & 9 & 8.0 \\
MN-53 & 16.04 & 20.04 & 20.04 & 19.04 & 6 & 7 & 3 & 5.3 \\
MN-59 & 16.04 & 20.04 & 19.04 & 18.04 & 7 & 4 & 4 & 5.0 \\
Average & - & - & - & - & 7.4 & 6.0 & 5.7 & - \\
\hline
\end{tabular}

* 1-9 point scale (1 - no flowering, 3 - poor flowering, 5 - moderate flowering, 7 - abundant flowering, 9 - very abundant flowering.

During the three years of genotype evaluation, spring frosts were also recorded (Fig. 2a-c). The largest temperature drops in the spring occurred on 20 April $2009\left(-4.0^{\circ} \mathrm{C}\right)$ and 25 April $2010\left(-2.5^{\circ} \mathrm{C}\right)$. Literature data indicates that a temperature drop to $-2.2^{\circ} \mathrm{C}$ during full bloom may already be critical for apricot flowers (Rogers \& Swift, 1970 , as per Gunes, 2006). In our experiments, the frost events occurred when the evaluated genotypes were in full bloom (2009), or a few days after full bloom (2010) (Table 2), so their flowers were highly exposed to severe frost damage. In spite of that, trees of genotypes MN-4 and MN-46 blossomed profusely and set fruit well (Table 3), which is a clear indication of a high resistance of their flowers to spring frosts, as well as of their ability to set fruit in unfavourable temperature conditions.

Table 3. Fruit ripening time and intensity of fruiting of the evaluated apricot seed genotypes (Dabrowice, 2008-2010)

\begin{tabular}{llllllllll}
\hline \multirow{3}{*}{ Genotype } & \multicolumn{3}{l}{ Fruit ripening time } & \multicolumn{1}{c}{ Intensity of fruiting* } \\
\cline { 2 - 9 } & \multicolumn{3}{l}{ Year of observation } \\
\cline { 2 - 9 } & 2008 & 2009 & 2010 & Average & 2008 & 2009 & 2010 & Average \\
\hline MN-1 & 18.08 & 18.08 & 21.08 & 19.08 & 6 & 4 & 6 & 5.3 \\
MN-2 & 22.08 & 20.08 & 28.08 & 23.08 & 7 & 4 & 6 & 5.7 \\
MN-4 & 30.07 & 23.07 & 23.07 & 25.07 & 8 & 6 & 8 & 7.3 \\
MN-6 & 25.08 & 27.08 & 29.08 & 27.08 & 6 & 5 & 6 & 5.7 \\
MN-46 & 01.08 & 28.07 & 28.07 & 29.07 & 8 & 6 & 8 & 7.3 \\
MN-53 & 20.07 & 25.07 & 25.07 & 23.07 & 5 & 5 & 4 & 4.7 \\
MN-59 & 30.08 & 04.09 & 05.09 & 03.09 & 6 & 3 & 6 & 5.0 \\
Average & - & - & - & - & 6.6 & 4.7 & 6.3 & - \\
\hline
\end{tabular}

* 1-9 point scale (1-no fruiting, 3 - poor fruiting, 5 - moderate fruiting, 7 - abundant fruiting, 9 - very abundant fruiting.

In addition to regular fruiting, what is also important in the case of seed genotypes of apricot is the number of fruit harvested, which translates into the number of seed-containing stones. Therefore, apricot seed trees are not expected to produce large fruit, but a large number of preferably small fruit (Indreias \& Trandafirescu, 1999). In our study, this condition was fully met by genotypes MN-4 and MN-46, which produced fruit with an average weight of $16.7 \mathrm{~g}$ and $17.3 \mathrm{~g}$, respectively. They were almost $50 \%$ smaller than the fruit of genotypes MN-1 (32.3 g) and MN-2 (31.3 g), which produced the largest fruit (Table 4). 
Table 4. Mean fruit weight and weight of one dried stone of the evaluated apricot seed genotypes

\begin{tabular}{lccccccc}
\hline \multirow{2}{*}{ Genotype } & \multicolumn{3}{c}{ Mean fruit weight $(\mathrm{g})$} & \multicolumn{3}{c}{ Weight of one dried stone $(\mathrm{g})^{*}$} \\
\cline { 2 - 8 } & 2008 & 2009 & 2010 & Average & 2009 & 2010 & Average \\
\hline MN-1 & $27^{\mathrm{c}^{\text {** }}}$ & $42^{\mathrm{b}}$ & $28^{\mathrm{d}}$ & $32.3^{\mathrm{d}}$ & $2.38^{\mathrm{d}}$ & $1.66^{\mathrm{d}}$ & $2.02^{\mathrm{e}}$ \\
MN-2 & $26^{\mathrm{c}}$ & $41^{\mathrm{b}}$ & $27^{\mathrm{d}}$ & $31.3^{\mathrm{d}}$ & $1.49^{\mathrm{b}}$ & $1.06^{\mathrm{b}}$ & $1.28^{\mathrm{c}}$ \\
MN-4 & $12^{\mathrm{a}}$ & $25^{\mathrm{a}}$ & $13^{\mathrm{a}}$ & $16.7^{\mathrm{a}}$ & $1.61^{\mathrm{c}}$ & $0.94^{\mathrm{a}}$ & $1.28^{\mathrm{c}}$ \\
MN-6 & $14^{\mathrm{ab}}$ & $28^{\mathrm{a}}$ & $16^{\mathrm{bc}}$ & $19.4^{\mathrm{c}}$ & $1.24^{\mathrm{a}}$ & $1.06^{\mathrm{b}}$ & $1.15^{\mathrm{a}}$ \\
MN-46 & $12^{\mathrm{a}}$ & $26^{\mathrm{a}}$ & $14^{\mathrm{ab}}$ & $17.3^{\mathrm{ab}}$ & $1.53^{\mathrm{b}}$ & $0.92^{\mathrm{a}}$ & $1.23^{\mathrm{b}}$ \\
MN-53 & $15^{\mathrm{b}}$ & $28^{\mathrm{a}}$ & $17^{\mathrm{c}}$ & $20.0^{\mathrm{c}}$ & $1.24^{\mathrm{a}}$ & $1.07^{\mathrm{b}}$ & $1.16^{\mathrm{a}}$ \\
MN-59 & $13^{\mathrm{ab}}$ & $28^{\mathrm{a}}$ & $15^{\mathrm{abc}}$ & $18.7^{\mathrm{bc}}$ & $1.61^{\mathrm{c}}$ & $1.17^{\mathrm{c}}$ & $1.39^{\mathrm{d}}$ \\
\hline
\end{tabular}

* Assessed only in 2009 and 2010.

** Means in columns followed by the same letter do not differ significantly (5\%) according to Duncan's t-test.

Production of small fruit makes it possible to obtain a large number of stones (seeds) from the harvested fruit crop. It was thus calculated that from one tonne of fruit of genotypes MN-4 and MN-46 it is possible to obtain 66752 and 64408 stones, respectively, which is more than twice as many as, for example, from one tonne of fruit of genotypes MN-2 and MN-1, from which one can get 33296 and 32187 stones, respectively (Table 5). This indicates that of all the genotypes under evaluation, genotypes MN-4 and MN-46 would give the highest yield of seeds from a seed orchard.

Table 5. Number of stones obtained from 1 tonne of fresh fruit and the number of dried stones per $\mathrm{kg}$

\begin{tabular}{|c|c|c|c|c|c|c|c|}
\hline \multirow[t]{2}{*}{ Genotype } & \multicolumn{4}{|c|}{ Number of stones obtained from 1 tonne of fruit } & \multicolumn{3}{|c|}{$\begin{array}{l}\text { Number of dried stones per } 1 \\
\mathrm{~kg} *\end{array}$} \\
\hline & 2008 & 2009 & 2010 & Average & 2009 & 2010 & Average \\
\hline MN-1 & $37037^{2^{* *}}$ & $23810^{\mathrm{a}}$ & $35714^{\mathrm{a}}$ & $32187^{\mathrm{a}}$ & $419^{\mathrm{a}}$ & $601^{\mathrm{a}}$ & $510^{\mathrm{a}}$ \\
\hline MN-2 & $38462^{\mathrm{a}}$ & $24390^{\mathrm{a}}$ & $37037^{\mathrm{a}}$ & $33296^{\mathrm{a}}$ & $669^{\mathrm{c}}$ & $939^{\mathrm{c}}$ & $804^{\mathrm{c}}$ \\
\hline MN-4 & $83333^{\mathrm{c}}$ & $40000^{\mathrm{c}}$ & $76923^{\mathrm{d}}$ & $66752^{\mathrm{d}}$ & $620^{\mathrm{b}}$ & $1054^{\mathrm{d}}$ & $837^{\mathrm{d}}$ \\
\hline MN-6 & $71429^{b}$ & $35714^{\mathrm{b}}$ & $62500^{\mathrm{bc}}$ & $56548^{\mathrm{bc}}$ & $800^{\mathrm{d}}$ & $941^{\mathrm{c}}$ & $870^{\mathrm{e}}$ \\
\hline MN-46 & $83333^{\mathrm{c}}$ & $38462^{\mathrm{bc}}$ & $71429^{\text {cd }}$ & $64408^{\mathrm{d}}$ & $652^{\mathrm{c}}$ & $1079^{\mathrm{d}}$ & $865^{\mathrm{e}}$ \\
\hline $\mathrm{MN}-53$ & $66667^{b}$ & $35714^{\mathrm{b}}$ & $58824^{\mathrm{b}}$ & $53735^{\mathrm{b}}$ & $801^{\mathrm{d}}$ & $932^{\mathrm{c}}$ & $866^{\mathrm{e}}$ \\
\hline MN-59 & $77852^{\mathrm{bc}}$ & $35714^{b}$ & $66667^{b c}$ & $59768^{\mathrm{c}}$ & $619^{b}$ & $855^{\mathrm{b}}$ & $737^{b}$ \\
\hline
\end{tabular}

* Assessed only in 2009 and 2010.

** As for Table 4 .

The bearing of small fruit by genotypes MN-4 and MN-46 also translates into a low weight of stones. The mean weight of one dried stone of genotype MN-4 was $1.28 \mathrm{~g}$, and that of genotype MN-46-1.23 g (Table 4). An advantage of small stones is that they allow to reduce the costs associated with harvesting, storing, and subjecting them to stratification. Table 5 shows that the number of stones that make up the weight of $1 \mathrm{~kg}$ is highest for genotypes MN-6 (870 stones), MN-53 (866 stones), MN-46 (865 stones) and MN-4 (837 stones), and the lowest for genotype MN-1 (510 stones).

\subsection{Seed Germination}

The suitability of seeds for the production of generative rootstocks for apricot cultivars depends on their capacity to germinate. A high germination rate increases the number of rootstocks obtained in relation to the number of seeds sown. The seeds of all the genotypes in this study had the highest germination rate in 2011 - an average of $85.9 \%$ (Table 6c), and the lowest in 2009 - an average of $29.9 \%$ (Table 6a). This variation in seed germination capacity may have been caused by weather conditions (Table 1). During the growing seasons of 2009 and 2010, higher temperatures were recorded and more rainfall occurred than in 2008. Different germination capacities of the seeds of fruit trees as affected by the growing season had earlier been found also for sweet cherry (Suszka, 1976a, 1976b), apple (Lewandowski \& Żurawicz, 2009a, 2009b), and peach (Szymajda, Żurawicz, \& Sitarek, 2011). 
Furthermore, the seeds of different apricot genotypes can have different germination capacities (Layne, Catherine, \& Hough, 1996; Bassi, Masia, \& Lugaresi, 1999; Dimitrowa, 2000; Kramarenko, 2006). The three-year results of our study show that the best germination capacity have the seeds of genotypes MN-4 and MN-46. Seed germination rate for genotype MN-4 was $27.8 \%$ in $2009,76.0 \%$ in 2010 and $100 \%$ in 2011 , while the seeds of MN-46 germinated at 59.0\% in 2010 and 100\% in 2011 (Table 6a-c). Layne et al. (1996) and Dimitrowa (2000) have reported that the seeds of early-ripening apricot cultivars generally germinate at a lower rate than the seeds of cultivars maturing later. Noteworthy, then, is the fact that the seed trees of genotypes MN-4 and MN-46 studied by us produce seeds with a high germination capacity although they are characterized by an earlier fruit ripening time than genotypes MN-1, MN-2, MN-6 and MN-59 (Table 3).

Table 6. Germination dynamics of stratified apricot seeds (stones) a) in 2009, b) in 2010, c) in 2011

a)

\begin{tabular}{|c|c|c|c|c|c|c|c|}
\hline \multirow{2}{*}{ Genotype } & \multicolumn{7}{|c|}{ Percentage of germinated seeds after $50-110$ days of stratification } \\
\hline & 50 & 60 & 70 & 80 & 90 & 100 & 110 \\
\hline $\mathrm{MN}-2$ & 11.4 & 23.2 & 32.2 & 36.2 & 43.2 & 43.2 & $43.2^{\mathrm{c}^{*}}$ \\
\hline MN-4 & 1.8 & 5.4 & 15.2 & 19.4 & 26.4 & 27.8 & $27.8^{\mathrm{b}}$ \\
\hline MN-6 & 6.4 & 8.4 & 26.4 & 32.4 & 35.6 & 36.0 & $36.0^{\mathrm{bc}}$ \\
\hline MN-59 & 1.0 & 2.2 & 8.8 & 10.0 & 11.4 & 11.8 & $12.4^{\mathrm{a}}$ \\
\hline Average & 5.2 & 9.8 & 20.7 & 24.5 & 29.2 & 29.7 & 29.9 \\
\hline
\end{tabular}

* Means in columns marked with the same letter do not differ significantly (5\%) according to Duncan's t-test.

b)

* As for Table 6 a.

\begin{tabular}{|c|c|c|c|c|c|c|c|}
\hline \multirow{2}{*}{ Genotype } & \multicolumn{7}{|c|}{ Percentage of germinated seeds after $50-110$ days of stratification } \\
\hline & 50 & 60 & 70 & 80 & 90 & 100 & 110 \\
\hline $\mathrm{MN}-1$ & 3.8 & 16.4 & 39.6 & 45.4 & 46.2 & 47.4 & $47.4^{\mathrm{b}^{*}}$ \\
\hline $\mathrm{MN}-2$ & 5.8 & 6.6 & 26.4 & 26.6 & 28.8 & 29.2 & $29.2^{\mathrm{a}}$ \\
\hline $\mathrm{MN}-4$ & 0.4 & 20.6 & 61.4 & 75.0 & 76.0 & 76.0 & $76.0^{\mathrm{d}}$ \\
\hline MN-6 & 5.8 & 19.8 & 38.8 & 47.2 & 48.6 & 49.0 & $49.0^{\mathrm{b}}$ \\
\hline MN-46 & 2.0 & 21.6 & 41.8 & 55.0 & 56.8 & 59.0 & $59.0^{c}$ \\
\hline MN-53 & 0.0 & 18.2 & 60.6 & 79.2 & 80.2 & 80.2 & $80.2^{\mathrm{d}}$ \\
\hline MN-59 & 0.0 & 12.2 & 53.4 & 62.4 & 62.4 & 62.4 & $62.4^{\mathrm{c}}$ \\
\hline Average & 2.5 & 16.5 & 46.0 & 55.9 & 57.0 & 57.6 & 57.6 \\
\hline
\end{tabular}

c)

\begin{tabular}{lrrrllrr}
\hline \multirow{2}{*}{ Genotype } & \multicolumn{6}{c}{ Percentage of germinated seeds after 50-110 days of stratification } \\
\cline { 2 - 8 } & \multicolumn{1}{r}{50} & \multicolumn{1}{c}{70} & 80 & 90 & 100 & \multicolumn{1}{c}{110} \\
\hline MN-1 & 6.0 & 13.6 & 29.2 & 60.4 & 76.2 & 80.8 & $88.4^{\mathrm{b}^{*}}$ \\
MN-2 & 10.2 & 16.2 & 44.4 & 76.4 & 79.0 & 85.4 & $90.2^{\mathrm{b}}$ \\
MN-4 & 0.0 & 0.6 & 5.2 & 42.8 & 89.8 & 96.6 & $100.0^{\mathrm{c}}$ \\
MN-6 & 12.6 & 23.4 & 48.0 & 58.2 & 59.6 & 61.0 & $63.2^{\mathrm{a}}$ \\
MN-46 & 0.8 & 2.6 & 34.0 & 94.2 & 96.6 & 100.0 & $100.0^{\mathrm{c}}$ \\
MN-53 & 1.6 & 9.8 & 32.2 & 52.2 & 56.2 & 57.8 & $60.2^{\mathrm{a}}$ \\
MN-59 & 0.0 & 1.4 & 25.4 & 75.0 & 88.2 & 97.2 & $99.6^{\mathrm{c}}$ \\
Average & 4.5 & 9.7 & 31.2 & 65.6 & 77.9 & 82.7 & 85.9 \\
\hline
\end{tabular}

* As for Table 6a. 
As the results in Tables 6a-c show, the seeds of the evaluated apricot genotypes began to germinate after 50 days of stratification, but the most seeds germinated between day 70 and day 90 of stratification. After that period, not many seeds germinated. Seed germination after a similar period of stratification was also obtained by Jakubowski (2004). As already mentioned, knowing the optimal length of the stratification period for apricot seeds is very useful in nursery production. On its basis it is possible to set the time for subjecting seeds to stratification depending on the planned date of sowing them.

\subsection{Tree Growth Vigour}

Measurements of the trunk circumference showed that genotypes MN-59, MN-46, MN-53 and MN-4 are characterized by a lower growth vigour, as expressed by the trunk cross-sectional area, than genotypes $\mathrm{MN}-1$, MN-2 and MN-6 (Table 7). It can therefore be assumed that the rootstocks for apricot cultivars obtained from the seeds of the trees with a lower growth vigour will also be characterized by weaker growth. This would be a very valuable advantage of these rootstocks. Similar dependencies have been observed with generative rootstocks for peach. Rootstocks obtained from the seeds of the peach cultivar 'Syberian C' have a lower growth vigour than rootstocks obtained from the seeds of a local peach variety 'Rakoniewicka', which has a higher growth vigour than 'Syberian C' (Jakubowski, 2000). In relation to apricot, however, this aspect requires additional research, which will be undertaken in the near future.

Table 7. Tree growth vigour of the evaluated genotypes expressed as trunk cross-sectional area (Dąbrowice, 2011)

\begin{tabular}{llll}
\hline Genotype & Year of planting & $\begin{array}{l}\text { Tree age } \\
\text { (years) }\end{array}$ & TCSA $\left(\mathrm{cm}^{2}\right)$ \\
\hline MN-1 & 1997 & 14 & 535.4 \\
MN-2 & 1997 & 14 & 637.8 \\
MN-4 & 1997 & 14 & 293.0 \\
MN-6 & 1997 & 14 & 659.3 \\
MN-46 & 1997 & 14 & 203.0 \\
MN-53 & 1999 & 12 & 207.1 \\
MN-59 & 2000 & 11 & 185.4 \\
\hline
\end{tabular}

\section{Conclusions}

By conducting selection work it is possible to obtain seed genotypes of $P$. armeniaca that will provide annually large quantities of seeds needed to produce generative rootstocks for the cultivated varieties of apricot. Among the genotypes tested, the most suitable for harvesting seeds for the production of such rootstocks are genotypes MN-4 and MN-46. They bear fruit abundantly and regularly, produce small fruit and stones, and their seeds have a high capacity for germination. The regular fruiting of trees of these genotypes in spite of the freezing winter weather and spring frosts indicates their suitability for establishing apricot seed orchards in countries with colder climates at the northernmost extent of apricot cultivation.

Reliable fruiting of trees of apricot seed genotypes, high yields of seeds per tree and high germination rates of these seeds are important but not the only qualities that determine the usefulness of these genotypes in nursery and fruit-growing practice. There is a need to perform tests to check the compatibility of these rootstocks with the cultivars grafted on them and assess their fruit-growing value, which means assessing the effect of these rootstocks on the growth and fruiting of the scion cultivars and the health of trees in the orchard. Such studies are continuing.

\section{Acknowledgements}

This work was performed in the frame of Multi-annual Programme "Development of sustainable methods of horticultural production to ensure high biological and nutritional quality of horticultural products and to preserve the biodiversity of the environment and to protect its resources", financed by Polish Ministry of Agriculture and Rural Development; Task 6.1 "Creating of the biological progress and its using in the sustainable fruit production".

\section{References}

Audergon, J. M., Duquesne, J., Nicolas, J., \& Audubert, A. (1991). New selected rootstocks for apricot cultivars: Torinel. Acta Horticulturae, 293, 395-400.

Bassi, D., Masia, A., \& Lugaresi, M. (1999). Seed germination in several apricot cultivars. Acta Horticulturae, 484, 63-68. 
Chokoeva, M. D., \& Marinow, P. M. (1999). New apricot rootstocks. Acta Horticulturae, 488, 433-436.

Dimitrowa, M. (2000). Behaviour in the nursery field of some generative rootstocks for apricot. Acta Horticulturae, 538, 761-764.

Dimitrova, M., \& Marinov, P. (2002). Myrobalan (P. cerasifera Ehrh.) as a rootstock for apricot. Acta Horticulturae, 577, 315-318.

Duczmal, K. W., \& Tucholska, H. (2000). Nasiennictwo (Tom II). Poznań: Państwowe Wydawnictwo Rolne i Leśne.

Fadl, M. S., Bas, A. G., \& Tayel, S. (1978). The effect of low temperature on the dormancy 'Fayoumi' apricot seeds and on activities on native inhibit existing in their seed coats. Egypt Journal of Horticulture, 5(2), 105-114.

FAO. (2011). Food and Agriculture Organization of the United Nations. Retrieved from http://faostat.fao.org/site/567/DesktopDefault.aspx?PageID=567\#ancor

Geuna, F., Toschi, M., \& Bassi, D. (2003). The use of AFLP markers for cultivar identification in apricot. Plant Breeding, 122, 526-531. http://dx.doi.org/10.1111/j.1439-0523.2003.00897.x

Grzyb, Z. S., Zdyb, H., \& Sitarek, M. (1996). Wpływ różnych podkładek na zdrowotność, siłę wzrostu i owocowanie moreli. Zeszyty Naukowe Instytutu Sadownictwa i Kwiaciarstwa, 3, 55-62.

Gunes, N. T. (2006). Frost Hardiness of some Turkish apricot cultivars during the bloom period. HortScience, 41(2), 310-312.

Indreias, A., \& Trandafirescu, M. (1999). The behaviour in the nursery field of some generative rootstock genotypes for apricot. Acta Horticulturae, 488, 421-426.

Indreias, A., Stefan, I., \& Dutu, I. (2004). Apricot rootstocks created and used in Romania. Acta Horticulturae, 658, 509-511.

Jakubowski, T. (2000). Uprawa Brzoskwini i Nektaryny. Warszawa: Hortpress Sp. Zo.o.

Jakubowski, T. (2001). Uszkodzenia mrozowe pąków moreli w czasie zimy 2000/2001. XII Ogólnopolskie Seminarium Sekcji, Mrozoodporność 17-18 maja, 109-111.

Jakubowski, T. (2004). Uprawa moreli. Warszawa: Hortpress Sp. Zo.o.

Layne, R. E. C., Catherine, H. B., \& Hough, F. (1996). Apricot. In J. Janick, \& J. N. Moore, Fruit Breeding: Tree and Tropical Fruits (Vol. 1, pp. 79-111). New York: John Wiley \& Sons, Inc.

Kramarenko, L. (2006). Germination of apricot seeds. Acta Horticulturae, 701, 81-86.

Lewandowski, M., \& Żurawicz, E. (2009a). Kiełkowanie nasion jabłoni (Malus domestica) w zależności od krzyżowanych form rodzicielskich. Zeszyty Problemowe Postępów Nauk Rolniczych, 539(2), 433-440.

Lewandowski, M., \& Żurawicz, E. (2009b). The influence of genotype on germination of apples seeds. Acta Horticulturae, 814(1), 429-432.

Orero, G., Cuenca, J., Romero, C., Martinez - Calvo, J., Badenas, M. L., \& Llacer, G. (2004). Selection of Seedling rootstocks for apricot and almond. Acta Horticulturae, 658, 529-533.

Polat, A. A. (2007). The effects of various stratification durations on germination and seedling emergence rates of apricot seeds. International Journal of Natural and Engineering Sciences, 1(2), 45-48.

Rogers, W. J., \& Swift, H. L. (1970). Frost and the prevention of frost damage. U.S. Dept. Commerce NOAA: Silver Spring Md.

Rom, R. C. (1991). Apricot rootstocks: perspective, utilization and outlook. Acta Horticulturae, 293, 345-353.

Southwick, S. M., \& Weis, K. G. (1998). Selecting and propagating rootstocks to produce apricots. Hort Technology, 8(2), 164-170.

Suranyj, D. (1999). Wild apricot and myrobalan generative rootstocks for apricot cultivars. Acta Horticulturae, 488, 445-449.

Suszka, B. (1962). Wpływ czynnika termicznego na ustępowanie spoczynku nasion czereśni dzikiej. Arboretum Kórnickie, 7, 189-275.

Suszka, B. (1967). Studia nad spoczynkiem i kiełkowaniem nasion różnych gatunków z rodzaju Prunus L. Arboretum Kórnickie, 12, 221-282. 
Suszka, B. (1976a). Variability of the germination capacity of Mazzard cherry (Prunus avium L.) seeds collected from 10 trees in 5 different seasons. Arboretum Kórnickie, 21, 273-278.

Suszka, B. (1976b). Increase of germinative capacity of mazzard cherry (Prunus avium L.) seeds through the induction of secondary dormancy. Arboretum Kórnickie, 21, 257-270.

Szabo, Z., Soltesz, M., Buban, T., \& Nyeki, J. (1995). Low winter temperature injury to apricot flower buds in Hungary. Acta Horticulturae, 384, 273-276.

Szymajda, M., Żurawicz, E., \& Sitarek, M. (2011). Kiełkowanie nasion nowych genotypów nasiennych brzoskwini (Prunus persica L.). Zeszyty Naukowe ISK, tom 19, 15-24.

Szymajda, M., Pruski, K., Żurawicz, E., \& Sitarek M. (2013). Freezing injuries to flower buds and their influence on yield of apricot (Prunus armeniaca L.) and peach (Prunus persica L.). Canadian Journal of Plant Science, 93, 191-198. http://dx.doi.org/10.4141/cjps2012-238

Vachun, Z. (1995). Rootstocks for apricot - The current situation and main problems. Acta Horticulturae, 384, 459-465.

\section{Copyrights}

Copyright for this article is retained by the author(s), with first publication rights granted to the journal.

This is an open-access article distributed under the terms and conditions of the Creative Commons Attribution license (http://creativecommons.org/licenses/by/3.0/). 